
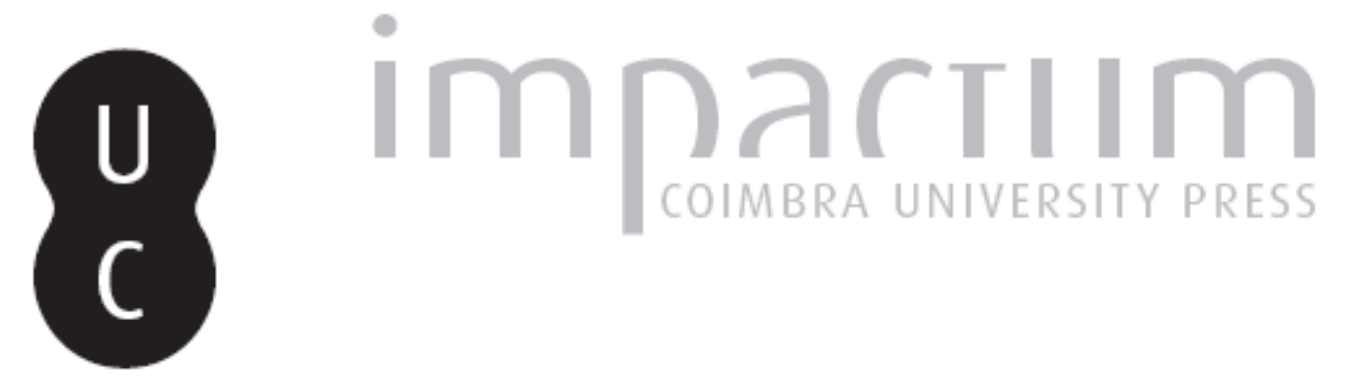

\title{
Eurípides, o mais trágico dos poetas (VI)
}

\author{
Autor(es): $\quad$ Silva, Maria de Fátima
}

Publicado por: Associação Portuguesa de Estudos Clássicos; Instituto de Estudos

URL $\quad$ URIsistente: $\quad$ URttp://hdl.handle.net/10316.2/30423

DOI: $\quad$ DOI:http://dx.doi.org/10.14195/0872-2110_50_1

Accessed : $\quad$ 26-Apr-2023 16:33:10

A navegação consulta e descarregamento dos títulos inseridos nas Bibliotecas Digitais UC Digitalis, UC Pombalina e UC Impactum, pressupõem a aceitação plena e sem reservas dos Termos e Condições de Uso destas Bibliotecas Digitais, disponíveis em https://digitalis.uc.pt/pt-pt/termos.

Conforme exposto nos referidos Termos e Condições de Uso, o descarregamento de títulos de acesso restrito requer uma licença válida de autorização devendo o utilizador aceder ao(s) documento(s) a partir de um endereço de IP da instituição detentora da supramencionada licença.

Ao utilizador é apenas permitido o descarregamento para uso pessoal, pelo que o emprego do(s) título(s) descarregado(s) para outro fim, designadamente comercial, carece de autorização do respetivo autor ou editor da obra.

Na medida em que todas as obras da UC Digitalis se encontram protegidas pelo Código do Direito de Autor e Direitos Conexos e demais legislação aplicável, toda a cópia, parcial ou total, deste documento, nos casos em que é legalmente admitida, deverá conter ou fazer-se acompanhar por este aviso.

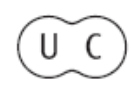




\section{Boletim de \\ Estudos Clássicos}

Associação Portuguesa de Estudos Clássicos Instituto de Estudos Clássicos

\section{Coimbra}

Dezembro de 2008 


\section{EuríPIDES, o Mais Trágico dos Poetas (VI)}

\section{O poeta e o pintor}

Além dos méritos de Eurípides, como dramaturgo e pensador, que temos vindo a valorizar em números anteriores desta publicação, importa que nos dediquemos agora a considerar alguns dos aspectos de excelência da sua criação poética. E, em primeiro lugar, impõe-se que sublinhemos um elemento particularmente marcante e identificativo da sua produção: o seu gosto e sensibilidade pelas descrições ou quadros pictóricos. Não que tal preferência fosse original na poesia grega; ela tinha já atrás de si uma longa tradição épica e lírica; mas, na tragédia, é sobretudo em Eurípides que esse filão encontra eco. De resto, a adopção, por parte de Eurípides, dessa tradição não é passiva; sofre uma reformulação que deixa entrever o poeta atraído pelo sucesso e novidade das artes plásticas suas contemporâneas, se não mesmo, como documentam alguns testemunhos antigos, a repartição do mesmo homem pelo pincel e pela pena.

Dos muitos motivos por que se reparte esta preferência, vamos focar um dos mais tradicionais: o que retrata cenas de amores divinos. Com um aparato de pormenores mais ou menos desenvolvido, a cena repete-se em Eurípides, obedecendo também a uma certa convenção de estilo e de linguagem. O enlace amoroso de Zeus e Hera, em Ilíada 14. 346-351, pode ser deste quadro um paradigma. A natureza cerca os amantes de frescura e colorido. Sob os corpos enlaçados, brota um tapete tenro de relva, que se matiza da tonalidade forte das flores. Uma nuvem de ouro, de onde goteja um doce orvalho, oculta os amantes. No conjunto, o recorte alvo dos corpos, que se estendem, relaxados, no verdor do solo, é filtrado por um véu dourado, que os salpica de brilhantes cintilações.

Eurípides cria, no Íon, o quadro do rapto de Creúsa, princesa ateniense, que, na solidão da natureza, entregue à tarefa bem feminina de colher flores, é raptada por um Apolo apaixonado. Eurípides introduz no quadro dos amores divinos um toque de violência, porque é contrariada que Creúsa se vê forçada a ceder ao deus. A descrição surge de repente, tão súbita como a própria aparição divina. Surpreendida, a donzela recolhia nas pregas do 
vestido as flores amarelas do açafrão, resplandecentes de tons doirados, como que reflectindo os raios ofuscantes que emanavam do deus da luz. A harmonia desta imagem opõe-se à brutalidade da cena seguinte: Apolo agarra os pulsos da jovem, brancos de fragilidade e desprotecção e, indiferente aos brados de protesto, arrasta-a para a sombra da caverna, onde toda a luminosidade se apaga, como que envergonhada do crime de que é testemunha.

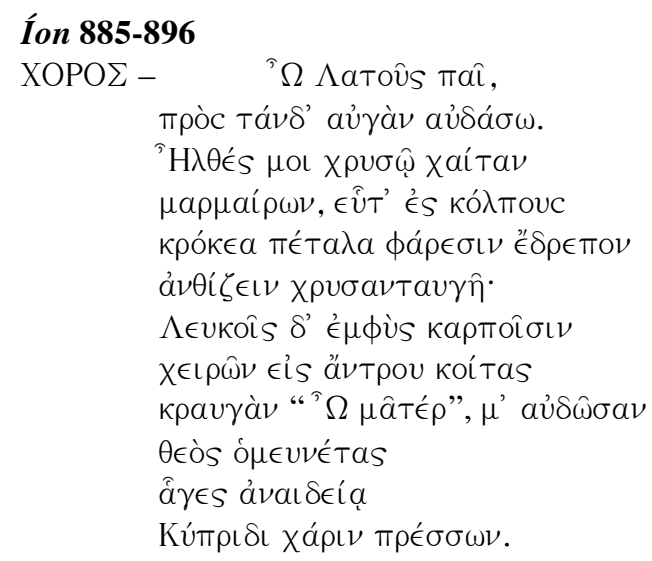

Filho de Latona, é diante deste sol que me ilumina que te acuso. Vieste ao meu encontro, envolto no resplendor dos teus cabelos de ouro, quando eu, nas pregas do vestido, colhia flores de açafrão, pétalas de reflexos de ouro, para entrelaçar grinaldas.

Agarraste-me os alvos pulsos, enquanto eu gritava: 'Mãe', e para o leito, nos recessos da caverna, me arrastaste, para aí cumprires, sem sombra de pudor, os desígnios de Cípris.

O mesmo tema do rapto, perpetrado por um imortal, de uma jovem que colhia flores, repete-se em Helena 243-247. Toda a força do quadro está, neste caso, centrada na figura feminina. $\mathrm{O}$ raptor, Hermes, que actua como emissário de Hera, não tem um empenho pessoal na acção, e por isso se retira para um plano secundário. Falta, a cobrir toda a cena, aquele resplendor que Apolo trouxera, no caso do Íon, com a sua aparição. Mas existe aqui também uma mulher solitária, Helena, que se entrega à tarefa de colher flores, que esconde nas pregas do vestido. As flores são, desta vez, rosas de pujante 
colorido. Sobre ela se precipita Hermes, para a agarrar à força e cruzar com a sua prisioneira as vastidões do céu, até um distante e inóspito Egipto.

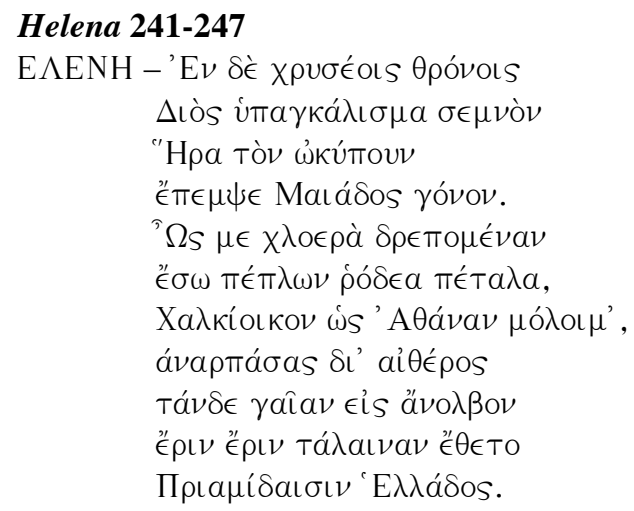

Então Hera, a deusa venerável que Zeus abraça no seu leito doirado, envia ao meu encontro o filho de Maia, Hermes de pés velozes. E enquanto eu, nas pregas do vestido, colhia frescas pétalas de rosa, para as oferecer à deusa que reina em seu trono de bronze, eis que Hermes me rapta e me leva pelos ares, até essa terra desolada. Assim me tornei, infeliz, o pomo de uma discórdia, de uma discórdia que confrontou o reino de Príamo com a Grécia.

Com estes quadros de uma enorme e relaxante beleza, o poeta satisfaz a necessidade das suas personagens, nas agruras da tragédia que vivem, de se refugiarem, por milagre da imaginação ou da memória, num paraíso distante onde, apesar de alguma violência, predomina a formosura.

M. F. S. S. 